FOLIA POMERANAE UNIVERSITATIS TECHNOLOGIAE STETINENSIS

Folia Pomer. Univ. Technol. Stetin., Oeconomica 2018, 344(91)2, 101-110

Grażyna VOSS, Piotr PREWYSZ-KWINTO*

\title{
PRAKTYKI JAKO ELEMENT PROCESU DYDAKTYCZNEGO - OCENA EFEKTÓW KSZTAKCENIA PRZEZ STUDENTÓW KIERUNKÓW EKONOMICZNYCH Z WYBRANYCH WOJEWÓDZTW
}

\section{PRACTICES AS A PART OF THE TEACHING PROCESS - EVALUATION OF EFFECTS OF EDUCATION ACCORDING TO STUDENTS OF ECONOMIC DIRECTIONS FROM SELECTED PROVINCE}

\author{
Katedra Organizacji i Zarządzania, Uniwersytet Technologiczno-Przyrodniczy im. Jana i Jędrzeja \\ Śniadeckich w Bydgoszczy, ul. Fordońska 430, 85-790 Bydgoszcz, e-mail: gvoss@wp.pl \\ *Katedra Finansów i Rachunkowości, Wyższa Szkoła Bankowa w Toruniu \\ ul. Młodzieżowa 31a, 87-100 Toruń
}

\begin{abstract}
Summary. Student internships are an essential part of the teaching process, whose task is to enable students to acquire professional competence and practical experience. Despite the strictly defined learning outcomes, students can not always complete all assignments and acquire specific skills. The range of student expectations and the differences they perceive in the practice are described on the basis of a survey conducted.
\end{abstract}

Słowa kluczowe: praktyka studencka, edukacja dorosłych, praktyczne i dydaktyczne aspekty praktyk.

Key worlds: student practice, adult education, practical and didactic aspects of practices.

\section{WSTĘP}

Edukacja dorosłych odbywa się na różnych poziomach kształcenia. Jednym z jej elementów jest studencka praktyka zawodowa, która stanowi ważny element kształcenia i prowadzona jest na różnych kierunkach studiów, w tym na kierunku zarządzanie oraz finanse i rachunkowość. Szczególne znaczenie praktyk studenckich wynika przede wszystkim z oczekiwań związanych z uzyskaniem doświadczenia i korzyści związanych z ich odbyciem (Mućko 2012). Zaangażowanie oraz właściwa postawa studenta podczas praktyk odgrywa istotne znaczenie w zdobywaniu nowych umiejętności i przygotowaniu do pracy zawodowej. Jednak w procesie kształcenia ważny jest zarówno proces nauczania, jak i uczenia się, dlatego warto zapytać samych zainteresowanych, jak postrzegają realizację praktyk studenckich w procesie kształcenia.

Celem artykułu jest zaprezentowanie wyników badania ankietowego, pozwalającego na ocenę praktyk studenckich zarówno pod względem sposobu ich realizacji, jak i proponowanych zmian w programie kształcenia studentów kierunków ekonomicznych z czterech uczelni województw pomorskiego i kujawsko-pomorskiego. 


\section{MATERIAŁ I METODY}

Badanie zostało przeprowadzone wśród studentów studiów niestacjonarnych drugiego stopnia z czterech uczelni (dwóch publicznych i dwóch niepublicznych) mających siedzibę na terenie województw pomorskiego i kujawsko-pomorskiego. Do udziału w badaniu zostały zaproszone osoby studiujące na kierunkach ekonomicznych zarządzanie oraz finanse i rachunkowość. Wszystkie osoby objęte badaniem w ramach programów kształcenia realizowały praktyki zawodowe w różnych podmiotach gospodarczych, przy czym wymieniany zakres tematyczny i liczba godzin nie zawsze były identyczne. Badanie zostało przeprowadzone w okresie od 15 maja do 15 czerwca 2017 roku z wykorzystaniem metody ankietowej. Przekazane respondentom kwestionariusze ankietowe zawierały 12 pytań, dotyczących zakresu i sposobu realizacji praktyk zawodowych oraz oceny ich efektów.

Pytania zawarte w kwestionariuszu badawczym miały charakter zamknięty lub otwarty. Część z nich wymagała udzielenia tylko odpowiedzi: tak albo nie. Jednak w większości pytań respondent był proszony o wybór jednego lub kilku wariantów spośród przedstawionych. Tam, gdzie to było możliwe i wydawało się zasadne, pozostawiano respondentom swobodę wyrażenia własnych opinii. Przy opracowywaniu wyników badania zostały wykorzystane metody statystyczne, ze szczególnym uwzględnieniem wskaźnika struktury.

Do udziału w badaniu przystąpiło 460 studentów, z czego poprawnie wypełnione kwestionariusze zwróciło 450 osób, co stanowi 97,8\%. Dziesięć kwestionariuszy zostało odrzuconych, gdyż nie zostały wypełnione poprawnie - nie udzielono odpowiedzi na wszystkie pytania lub zaznaczano więcej odpowiedzi niż wymagano.

Wśród respondentów, których kwestionariusze zostały poddane dalszej analizie, dominowały osoby studiujące na kierunku finanse i rachunkowość (315 osób), jednak kierunek studiów nie wpływał na charakter udzielonych odpowiedzi.

Szczegółowe informacje o osobach biorących udział w badaniu przedstawiono w tab. 1.

Tabela 1. Charakterystyka respondentów

\begin{tabular}{|l|l|c|c|}
\cline { 3 - 4 } \multicolumn{2}{c|}{} & N & Procent \\
\hline \multirow{2}{*}{ Kierunek studiów } & Finanse i rachunkowość & 315 & 70 \\
\cline { 2 - 4 } & Zarządzanie & 135 & 30 \\
\hline
\end{tabular}

\section{PRAKTYKI STUDENCKIE JAKO ELEMENT PROCESU DYDAKTYCZNEGO}

Programy studiów powinny odpowiadać wymogom współczesnej gospodarki i nadążać za zmianami, aby w jak najlepszy sposób przygotować absolwentów do wejścia na rynek pracy. W tym celu należy położyć większy nacisk na kształcenie praktyczne (Wiercińska 2016). Możliwość opracowania i wdrożenia autorskich programów kształcenia jest szansą na udoskonalenie oferty edukacyjnej uczelni (Hońko 2013), a jednocześnie na dostosowanie programów praktyk do potrzeb rynku i wymagań stawianych potencjalnym pracownikom. Programy praktyk bazują na efektach kształcenia realizowanych w ramach zajęć dydaktycznych, 
ale również realizowanych podczas zajęć praktycznych i określonych w sylabusach. Jednak czy efekty kształcenia, które są w nich zawarte, odpowiadają potrzebom rynku i są realizowane w sposób profesjonalny, pozwalający na zdobycie doświadczenia zawodowego i umiejętności praktycznych? Szukając odpowiedzi na to pytanie, przeprowadzono badanie ankietowe, mające na celu poznanie opinii studentów na temat powiązania wiedzy i umiejętności ze studencką praktyką zawodową.

\section{WYNIKI}

Analizę otrzymanych odpowiedzi rozpoczęto od ustalenia, czy odbywana przez respondentów praktyka w przedsiębiorstwach, realizowana była w sposób profesjonalny, zgodny z programem praktyk i pozwalający na zdobycie kompetencji zawodowych. Uzyskane wyniki zaprezentowano na ryc. 1.

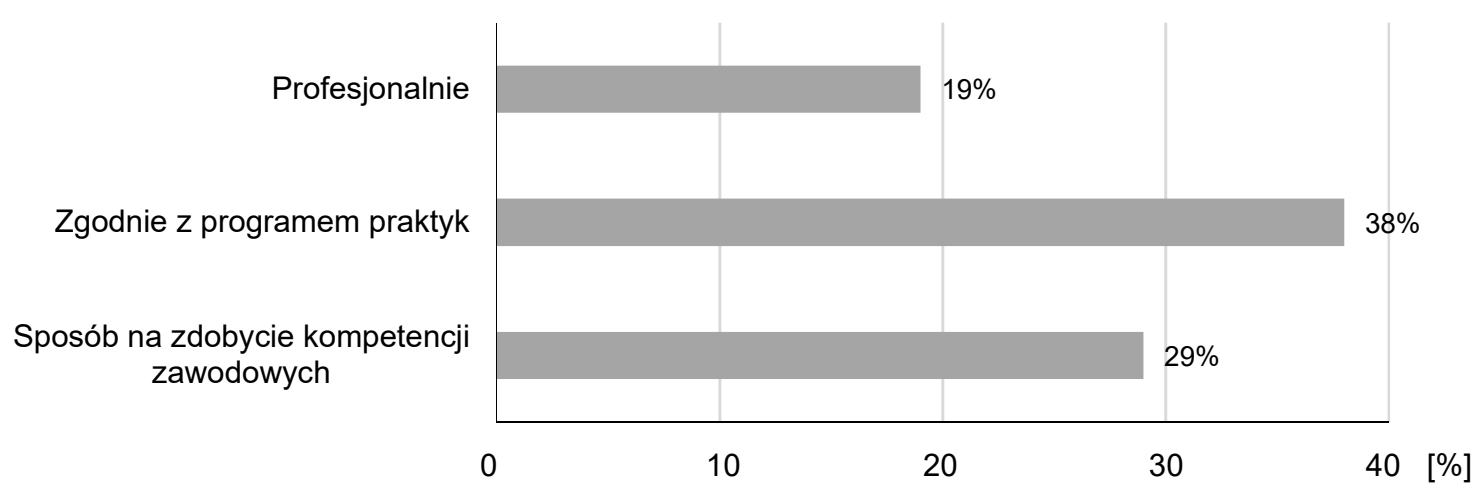

Ryc. 1. Ocena sposobu prowadzenia praktyk

Źródło: opracowano na podstawie przeprowadzonego badania.

Przedstawione wyniki ukazują, że zdecydowana większość respondentów nie była zadowolona z realizacji praktyk studenckich. Zaledwie 19\% badanych uważa, że przedsiębiorstwa prowadziły praktyki profesjonalnie, tylko 38\% respondentów uznało, że były realizowane zgodne z programem opisanym w sylabusie w zakresie zawartych efektów kształcenia, a co trzeci student (29\%) uznał, że dzięki praktykom mógł nabyć odpowiednie kompetencje zawodowe. Nasuwa się pytanie, czy tematyka praktyk jest dostosowana do możliwości realizacji zajęć w przedsiębiorstwach oraz czy studenci trafiający na praktyki mają możliwość wyboru przedsiębiorstwa przygotowanego na przyjęcie praktykantów, a także czy opiekunowie praktyk dysponują odpowiednim przygotowaniem i czasem niezbędnym na wdrożenie studenta do prac wykonywanych w ramach praktyk.

Respondentów zapytano także, czy w trakcie praktyk mieli możliwość zapoznać się z kodeksami etyki stosowanymi w przedsiębiorstwie, w którym odbywali praktyki. 59\% respondentów (266 osób) potwierdziło, że spotkało się z takimi kodeksami, przy czym najczęściej dotyczyły one etyki zawodowej. Uzyskane wyniki zostały przedstawione na ryc. 2. 
$[\%]$

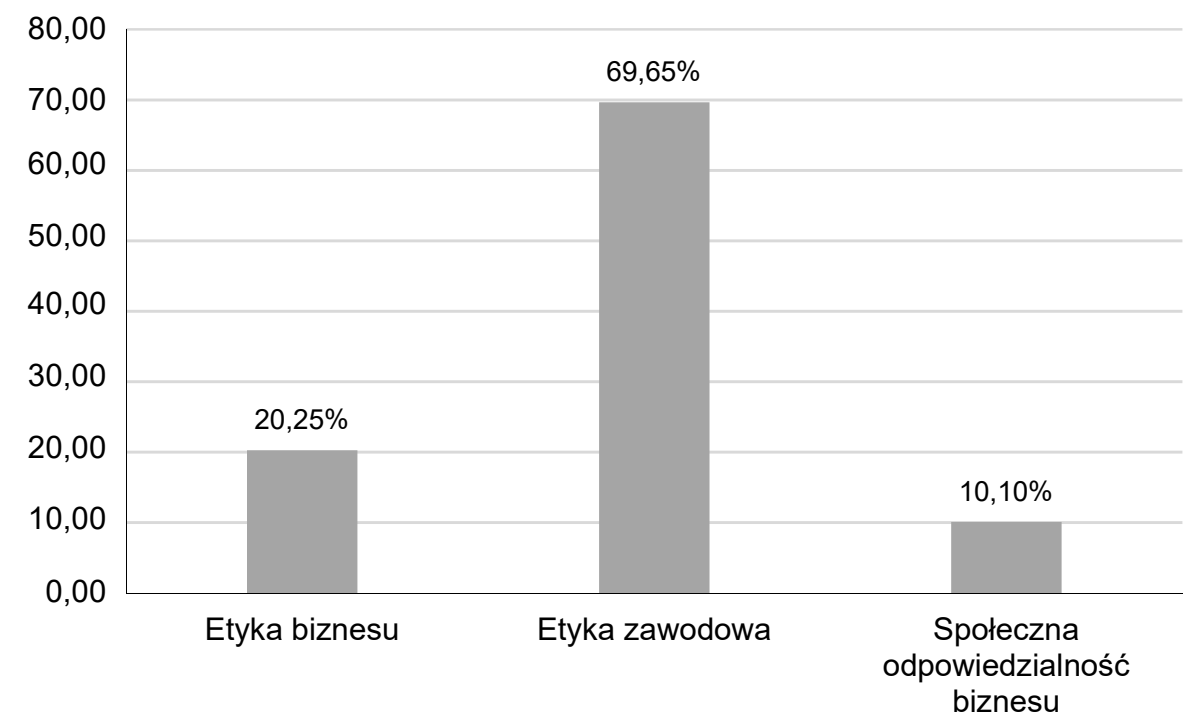

Ryc. 2. Obszary etyki realizowane w ramach praktyk studenckich Źródło: opracowano na podstawie przeprowadzonego badania.

Zgodnie z przedstawionym wykresem 705 respondentów w trakcie praktyki miało możliwość zapoznania się z etyką zawodową. Co piąty z badanych spotkał się z etyką biznesu, a zaledwie co dziesiąty miał możliwość zapoznania się ze społeczną odpowiedzialnością biznesu. Wyniki te wskazują, że większość podmiotów gospodarczych ukierunkowało swoje działania na przestrzeganie norm etycznych, a tworzenie wewnętrznych regulacji w zakresie przestrzegania zachowań etycznych staje się powszechne i stosowane w większości jednostek.

Kolejne pytanie ukierunkowane było na ocenę procedur kontrolnych i norm etycznych w jednostkach. Elementy te stanowią indywidualne rozwiązania w jednostkach gospodarczych, dlatego ich poznanie może stanowić istotną wartość dodaną w edukacji i w istotny sposób wpływać na rozwój nowych umiejętności i kompetencji zawodowych. Uzyskane wyniki zostały zaprezentowane na ryc. 3 .

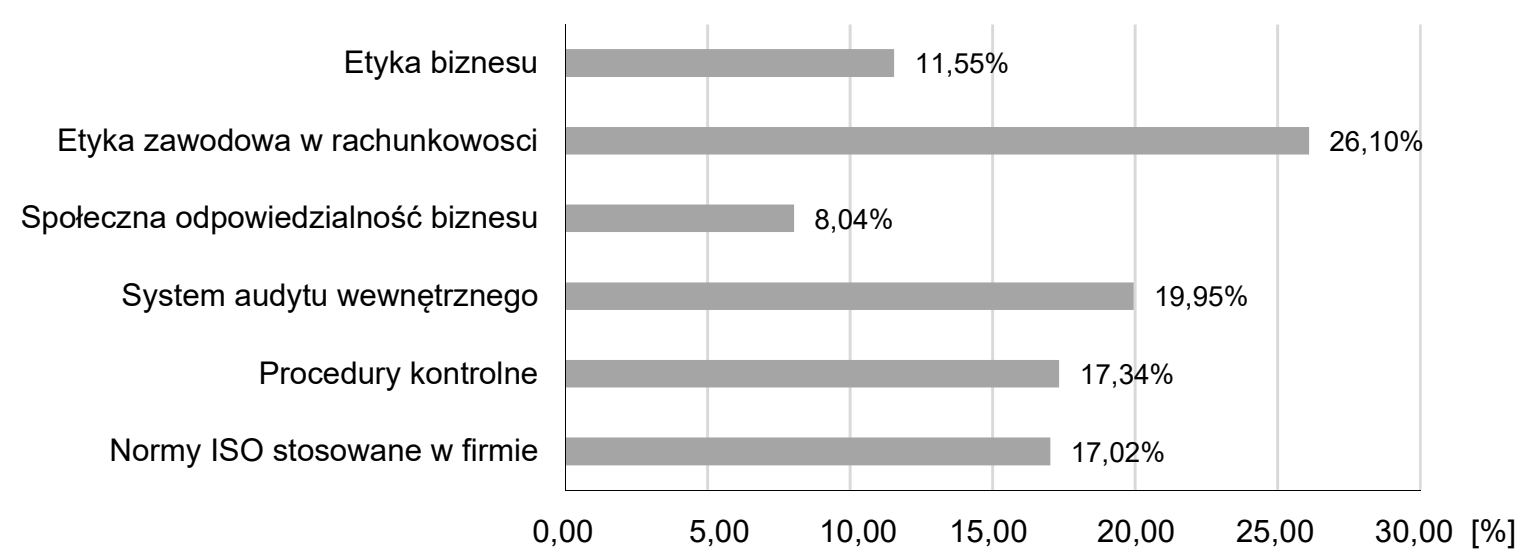

Ryc. 3. Procedury kontrolne i kodeksy etyczne jako nowe kompetencje społeczne realizowane w ramach praktyk

Źródło: opracowano na podstawie przeprowadzonego badania. 
Respondenci mieli możliwość zapoznania się z indywidualnymi rozwiązaniami stosowanymi w przedsiębiorstwach w zakresie stosowania procedur kontrolnych i przestrzegania norm etycznych. Najczęściej studenci mieli możliwość zapoznania się z etyką zawodową w rachunkowości (prawie 30\% respondentów) i procedurami audytu wewnętrznego (20\% badanych). Różnorodność stosowanych procedur kontrolnych i norm etycznych wskazuje na istotę omawianych zagadnień - zarówno z punktu widzenia realizacji praktyk, jak i funkcjonowania podmiotów gospodarczych.

W dalszej części kwestionariusza ankietowanym zadano pytanie, czy zakres realizowanych zadań w trakcie praktyki pozwolił na połączenie zdobytej wiedzy i umiejętności podczas procesu kształcenia w ramach realizowanych praktyk. Wyniki zaprezentowano na ryc. 4.

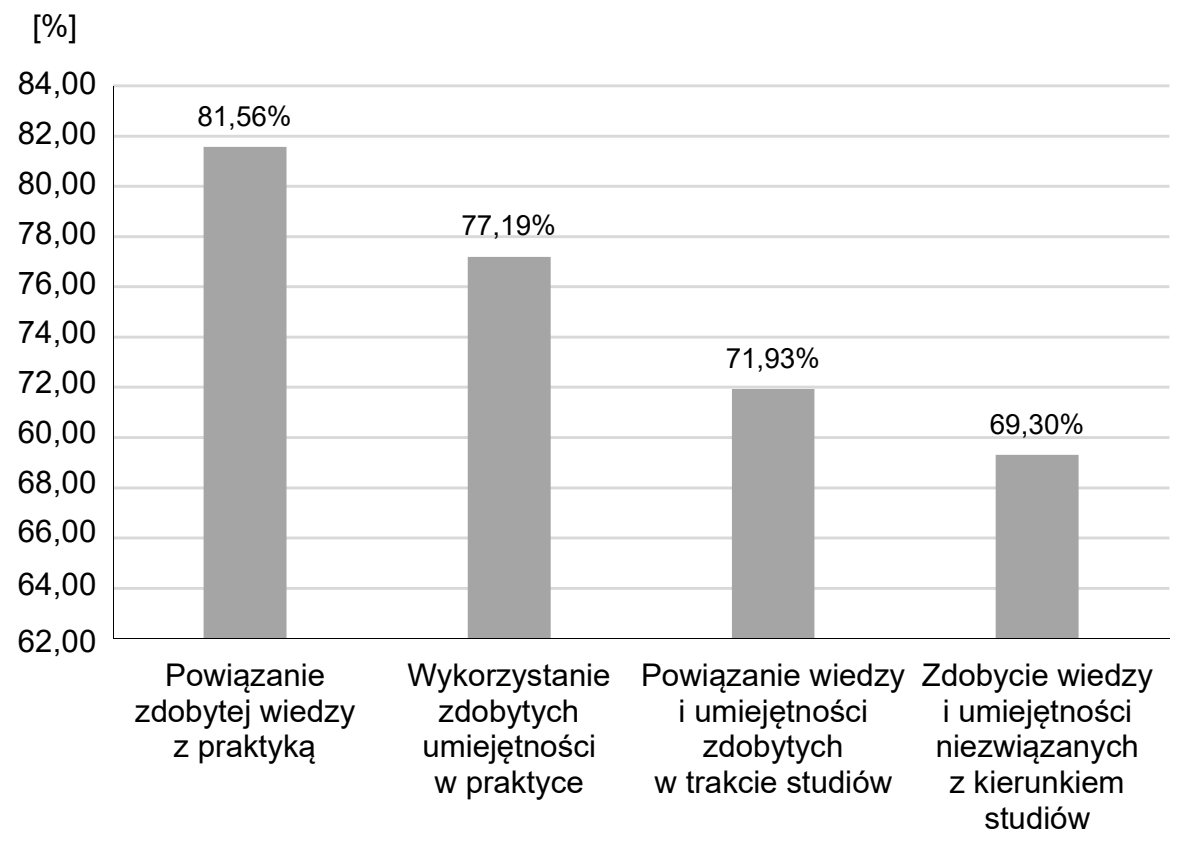

Ryc. 4. Powiązanie efektów kształcenia z praktyką

Źródło: opracowano na podstawie przeprowadzonego badania.

Ponad $80 \%$ respondentów uważa, że w ramach praktyk wykorzystywało wiedzę zdobytą podczas studiów. Jednak odsetek respondentów zmniejsza się, jeśli chodzi o wykorzystanie na praktykach zdobytych umiejętności (77\%). Na szczególną uwagę zasługują następne odpowiedzi. Ponad $70 \%$ badanych uważa, że poszerzyło swoją wiedzę i umiejętności zdobyte podczas studiów, a prawie $70 \%$ zdobyło nowe umiejętności, chociaż nie były one związane ze studiowanym kierunkiem. Odpowiedzi te wskazują, że tematyka praktyk i zakres realizowanych zadań w przedsiębiorstwach nie są sprecyzowane bądź firmy nie są w stanie zapewnić odpowiedniego rodzaju zajęć. Brak kompatybilności może wynikać również z niedostosowania tematyki praktyk do szybko zmieniających się warunków gospodarczych i zmian, jakie wdrażają przedsiębiorstwa w celu zachowania konkurencyjności na rynku.

Kolejne pytanie dotyczyło oceny powiązania wiedzy i umiejętności zdobytych podczas studiów z zadaniami realizowanymi w ramach praktyk. Prawie połowa ankietowanych $(48,22 \%)$ dobrze ocenia powiązanie wiedzy i umiejętności zdobytych w ramach praktyk. Na brak 
powiązań wskazało zaledwie $2 \%$ respondentów, co oznacza, że realizacja programów zajęć dydaktycznych pozwala na zdobycie solidnej podbudowy teoretycznej niezbędnej do realizacji zadań na stanowisku pracy w przedsiębiorstwie. Wyniki zaprezentowano na ryc. 5.

[\%]

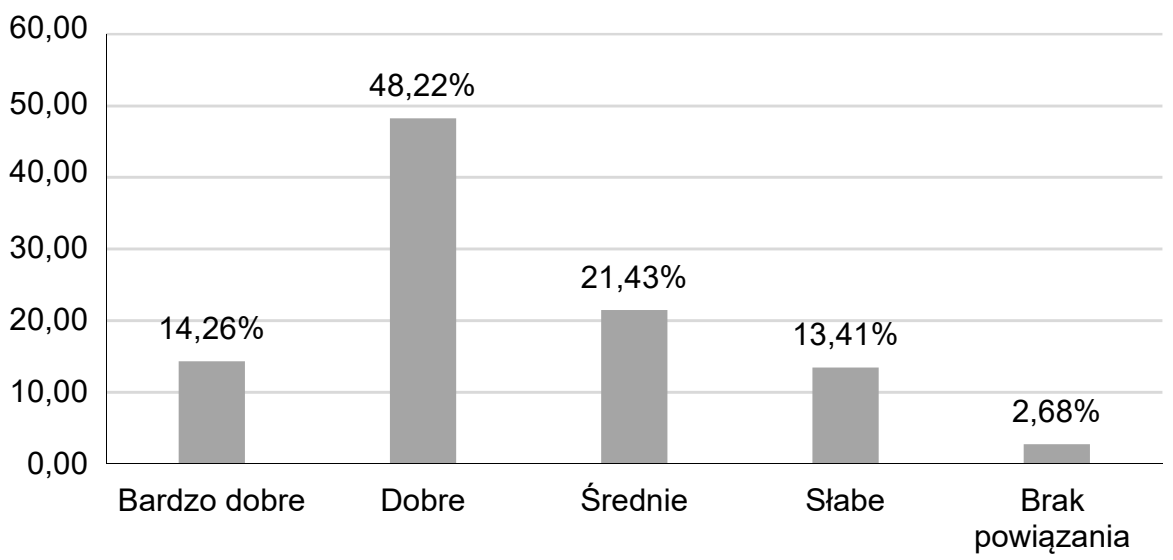

Ryc. 5. Powiązanie wiedzy i umiejętności zdobytych podczas studiów z praktyką Źródło: opracowano na podstawie przeprowadzonego badania.

W następnym pytaniu, dotyczącym organizacji i sposobu realizacji praktyk, respondenci zostali poproszeni o wskazanie, czy praktyki powinny być realizowane w jednym przedsiębiorstwie czy może w dwóch przedsiębiorstwach. 47\% respondentów uznała, że praktyka powinna być realizowana w jednym przedsiębiorstwie. Zdaniem 32\% respondentów praktyka powinna być realizowana w dwóch różnych jednostkach gospodarczych, jednak co piąty respondent uważa, że powinna być ona realizowana w zależności od wielkości przedsiębiorstwa - w jednym dużym przedsiębiorstwie, a w przypadku małych przedsiębiorstw - w dwóch różnych podmiotach. Wyniki te zaprezentowano na ryc. 6.

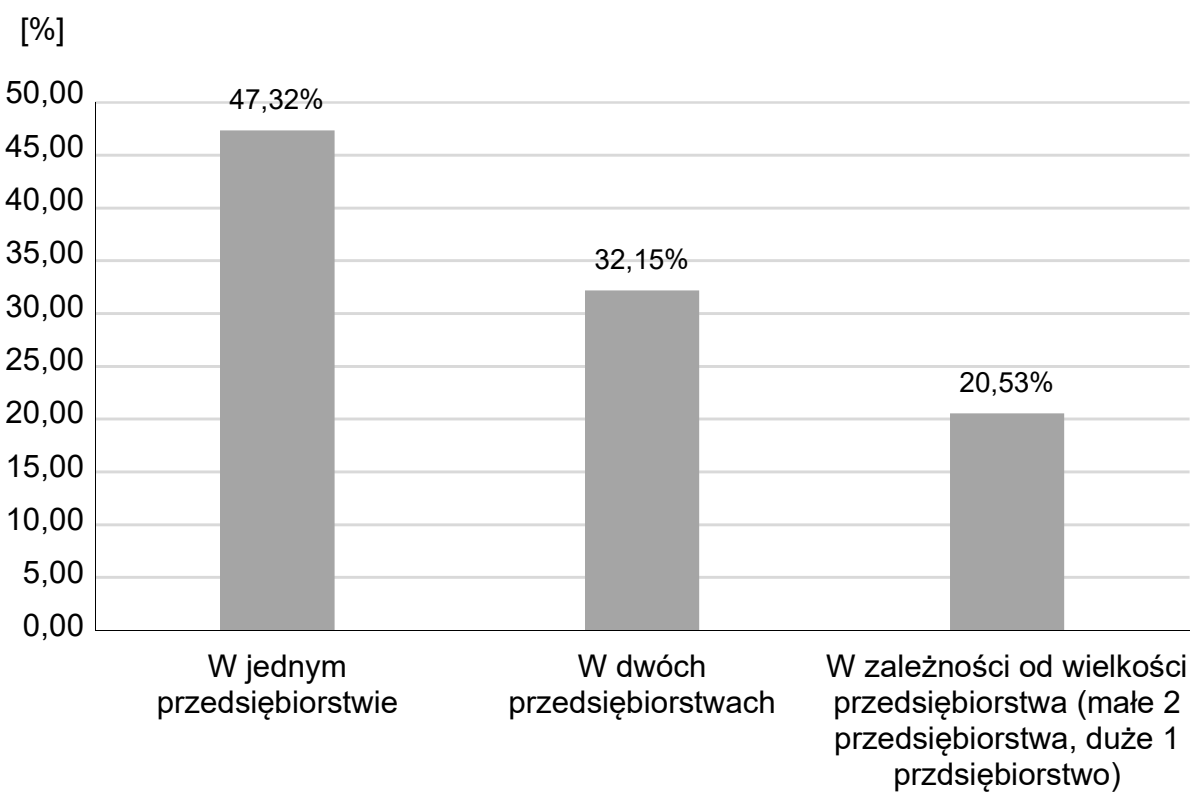

Ryc. 6. Realizacja praktyk w przedsiębiorstwach

Źródło: opracowano na podstawie przeprowadzonego badania. 
Otrzymane wyniki mogą świadczyć o tym, że duże przedsiębiorstwa mają więcej do zaoferowania podczas praktyk, jednak wybór 2 małych podmiotów może pozwolić na zapoznanie się z różnymi rozwiązaniami i różnymi branżami. Niewątpliwie odbycie praktyk w dwóch jednostkach wydaje się uzasadnione, szczególnie w przypadku studiów o profilu praktycznym.

Kolejne pytanie dotyczyło konieczności wprowadzenia zmian w systemie realizacji praktyk. Ponad 40\% respondentów uważa, że takie zmiany są konieczne, co zaprezentowano na ryc. 7 .

[\%]

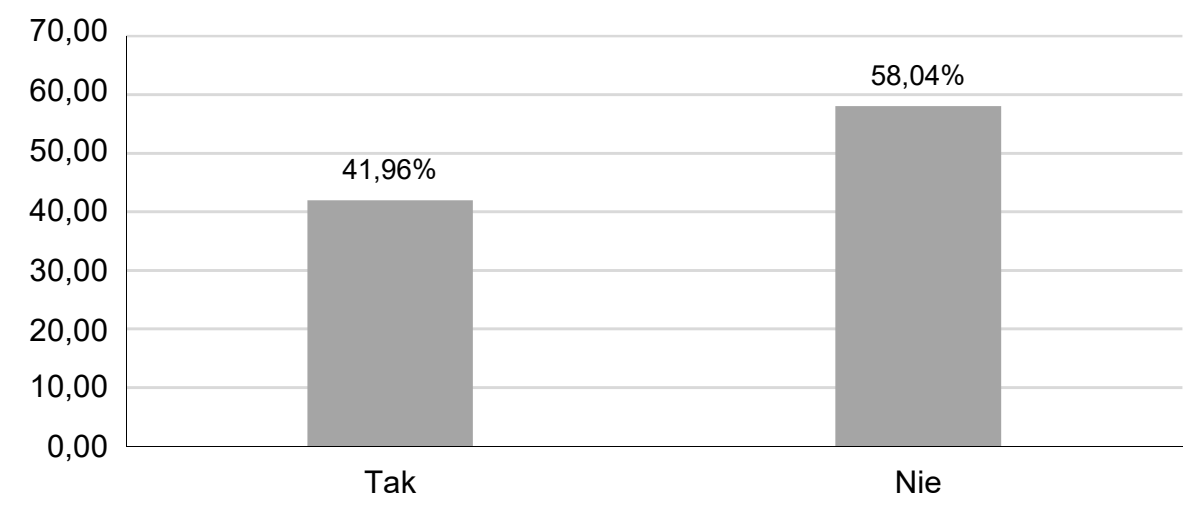

Ryc. 7. Konieczność wprowadzenia zmian w systemie praktyk Źródło: opracowano na podstawie przeprowadzonego badania.

Zdaniem studentów głównymi kierunkami zmian w praktykach jest zwiększenie współpracy uczelni z pracodawcami w celu wprowadzenia indywidualnych programów praktyk przez przedsiębiorcę. Ponadto co piąty respondent uważa, że należałoby zwiększyć liczbę godzin praktyk oraz ich zakres tematyczny. Uzyskane wyniki zaprezentowano na ryc. 8. Proponowane zmiany mogłyby w większym stopniu przygotować studentów (absolwentów) do wejścia na rynek pracy.

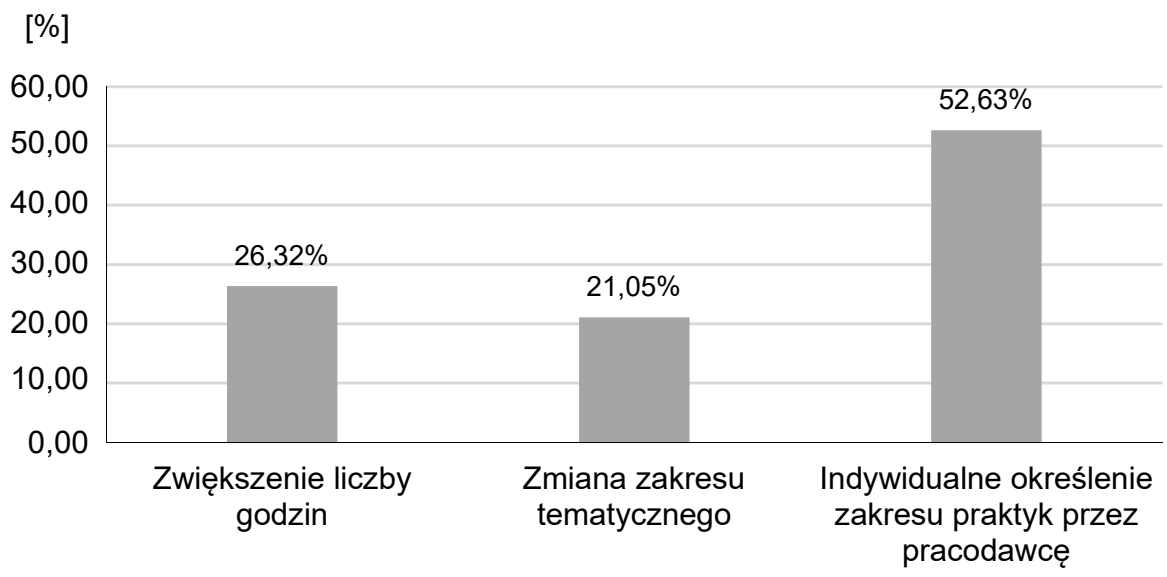

Ryc. 8. Zmiany w programach praktyk

Źródło: opracowano na podstawie przeprowadzonego badania.

Respondentów zapytano również, czy podczas praktyk zawodowych zapoznali się z zakresem obowiązków związanych ze stanowiskiem pracy, na którym realizowali prace w ramach praktyk. Uzyskane wyniki były dość jednoznaczne i nie zaskakiwały, gdyż prawie 
wszyscy ankietowani (94,64\%) odbyli szkolenie stanowiskowe i zostali zapoznani z zakresem prac i realizowanych czynności. Niestety, pomimo zapoznania się z zakresem obowiązków zakres ten i cała praktyka nie zawsze były zgodne z kierunkiem studiów. Co piąty ankietowany przyznaje, że wykonywane obowiązki nie były zgodne z kierunkiem studiów (zob. ryc. 9).

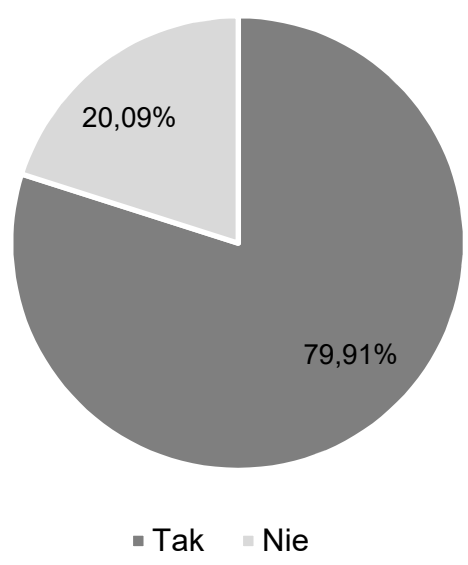

Ryc. 9. Zgodność realizowanych praktyk z kierunkiem studiów Źródło: opracowano na podstawie przeprowadzonego badania.

Kolejne pytanie było skierowane do grupy ankietowanych, którzy odbywali praktyki zgodnie z kierunkiem studiów. Co czwarty student (27\%) przyznał, że wykonywana praca pokrywała się z efektami kształcenia przewidzianymi w programie praktyk, ponad $40 \%$ uważała, że realizowana praktyka pokrywała się z programem częściowo. Pozostali respondenci uważali, że nie realizowała ona określonych efektów kształcenia lub trudno było im stwierdzić, czy zakres prac mieścił się w wymaganiach stawianych w programie praktyk. Wyniki zostały zaprezentowane na ryc. 10.

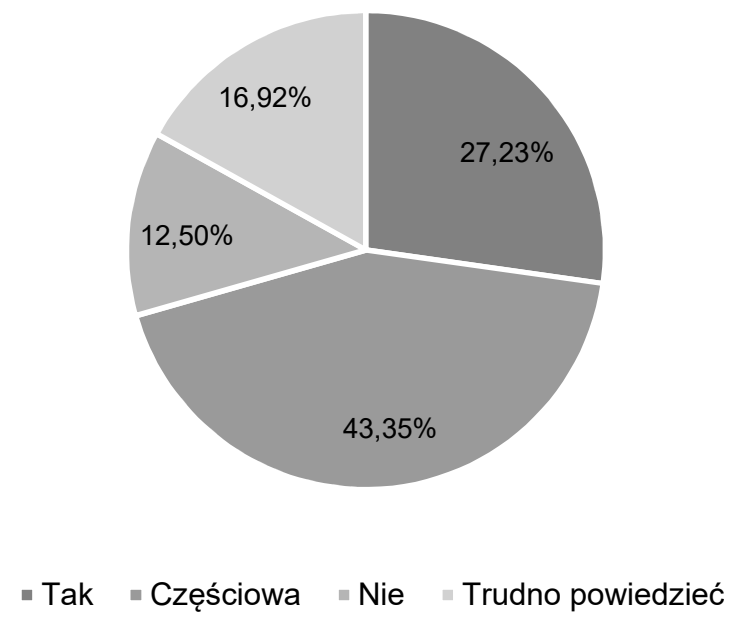

Ryc. 10. Zgodność realizowanych praktyk z zakładanymi efektami kształcenia Źródło: opracowano na podstawie przeprowadzonego badania.

Pomimo rozbieżności w zakresie realizacji efektów kształcenia poproszono respondentów o wskazanie, czy odbyte praktyki pozwoliły im na zdobycie wiedzy z innych obszarów niż $w$ trakcie realizacji studiów oraz czy zdobyli oni nowe umiejętności i kompetencje społeczne. 
Ponad $40 \%$ respondentów zdobyło wiedzę w innych obszarach, aniżeli miało to miejsce podczas realizacji procesu dydaktycznego na uczelniach. Prawie połowa studentów $(48,53 \%)$ uznała, iż praktyki pozwoliły im na zdobycie nowych umiejętności praktycznych; najmniejszy odsetek respondentów stanowili ci, którzy zdobyli nowe kompetencje społeczne. Wyniki zaprezentowano na ryc. 11.

[\%]

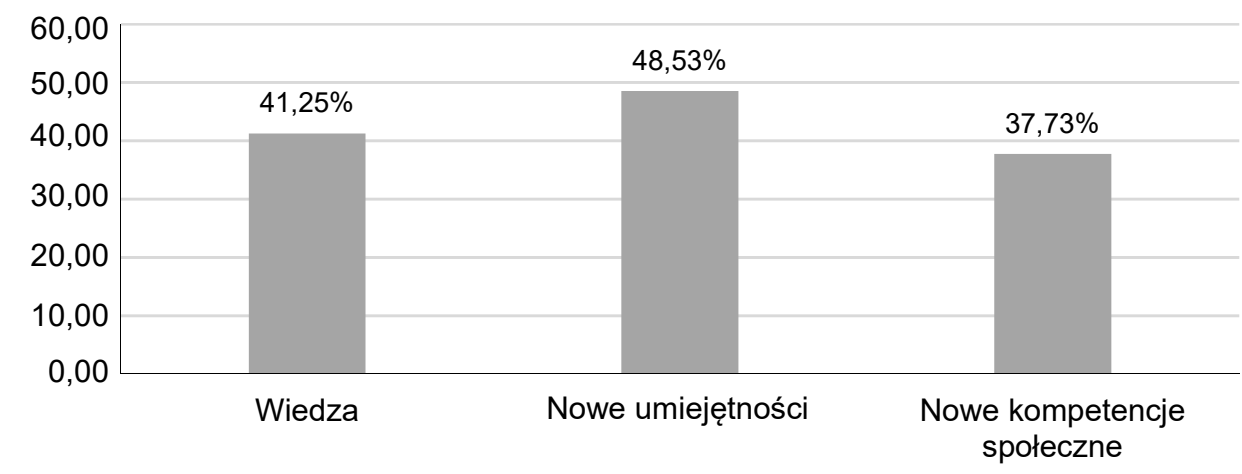

Ryc. 11. Obszary, w których respondenci zdobyli nowe efekty kształcenia Źródło: opracowano na podstawie przeprowadzonego badania.

Ostatnie pytanie skierowane do ankietowanych dotyczyło obszarów zmian, jakie respondenci wprowadziliby do programów praktyk; pytano także, o jakie zagadnienia rozwinęliby je, aby podnieść jakość kształcenie i zdobyć jak najlepsze przygotowanie do pracy. Najczęściej wymieniane obszary, w których respondenci zmieniliby zakres realizacji praktyk, to:

- obsługa programów komputerowych,

- zapoznanie się z kodeksami etycznymi i etyką zawodową,

- zapoznanie się $z$ dokumentacją wewnętrzną przedsiębiorstwa,

- znajomość regulacji prawnych.

Wyniki zostały zaprezentowane na ryc. 12.

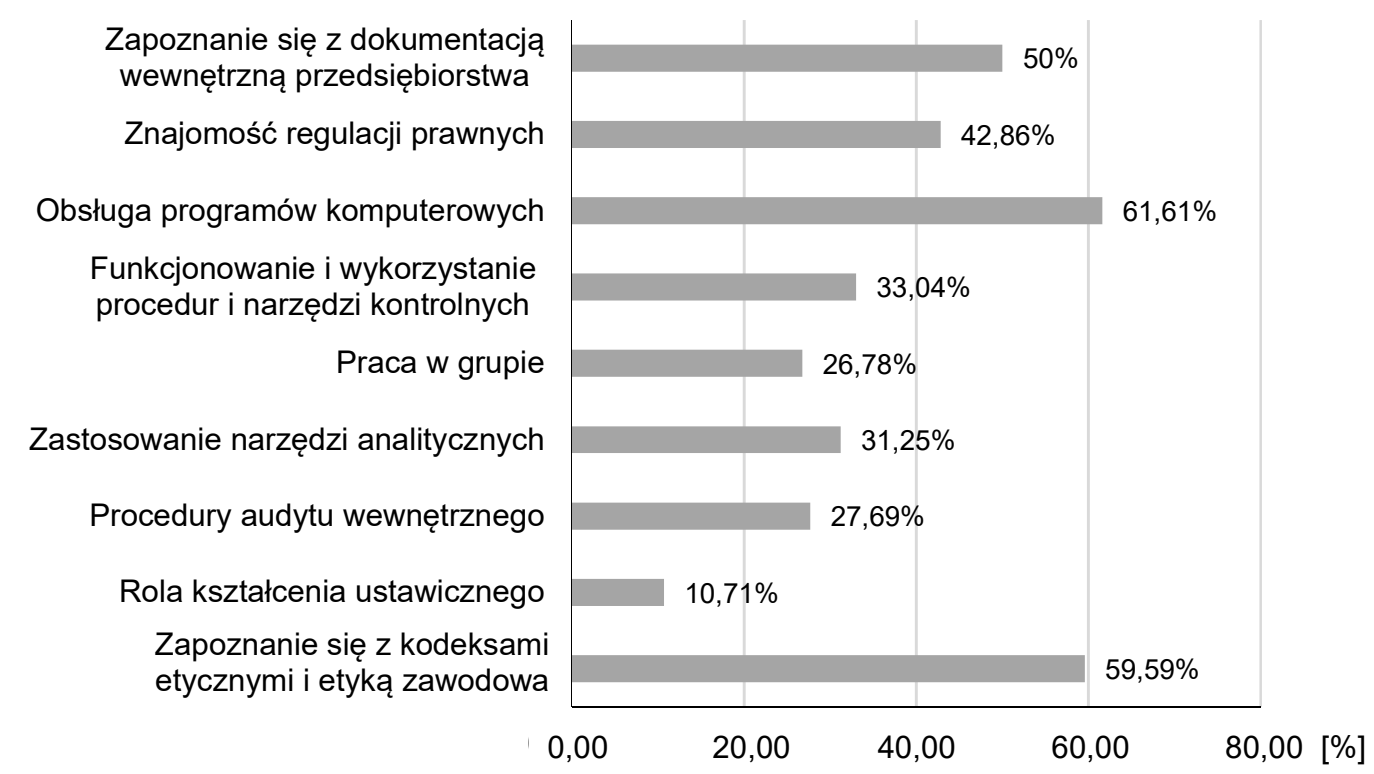

Ryc. 12. Obszary zmian i rozwoju zadań realizowanych w ramach praktyk Źródło: opracowano na podstawie przeprowadzonego badania. 


\section{PODSUMOWANIE}

$\mathrm{Na}$ podstawie przeprowadzonego wśród studentów z wybranych kierunków studiów z województw pomorskiego oraz kujawsko-pomorskiego badania ankietowego, dotyczącego realizacji praktyk w trakcie studiów, można sformułować następujące wnioski:

- praktyki studenckie nie są przygotowane i prowadzone w sposób profesjonalny, co obniża jej walory edukacyjne i korzyści, jakie mogłaby przynieść w poszukiwaniu pracy zawodowej przez absolwentów studiów;

- w ramach praktyk studenci spotykają się z etyką zawodową i poznają kodeksy etyczne, co zwiększa znaczenie tych zagadnień w procesie edukacji i jest zgodne z polską ramą kwalifikacyjną;

- zdecydowana większość respondentów potrafi powiązać i wykorzystać wiedzę, umiejętności i kompetencje społeczne w procesie realizacji praktyk;

- praktyka powinna być realizowana w dużym podmiocie gospodarczym lub w dwóch różnych podmiotach zaliczanych do sektora MSP;

- program praktyk powinien ulec modyfikacji, w szczególności pod względem realizacji efektów kształcenia;

- główne obszary zmian dotyczą zapoznania studentów z nowymi rozwiązaniami IT i kodeksami etycznymi.

Praktyka studencka stanowi nieodzowny element programu studiów, jednak zmiany w gospodarce wymuszają zmiany w programach praktyk, które powinny zagwarantować jak najlepsze przygotowanie absolwentów do wejścia na rynek pracy.

\section{PIŚMIENNICTWO}

Hońko S. 2013. Ocena efektów kształcenia z zakresu rachunkowości. Folia Pomer. Univ. Technol. Stetin., Oeconomica 294(67), 61.

Mućko P. 2012. Problemy obowiązkowych praktyk studenckich na kierunku finanse i rachunkowość. Folia Pomer. Univ. Technol. Stetin., Oeconomica 294(67), 264.

Prewysz-Kwinto P., Voss G. 2013. Metoda projektu według oceny studentów kierunków ekonomicznych. Wyniki badania ankietowego. Folia Pomer. Univ. Technol. Stetin., Oeconomica 303(72), 157.

Wiercińska A. 2016. Wzmocnienie praktycznych elementów kształcenia w szkolnictwie wyższym poprzez projekty finansowane z Europejskiego Funduszu Społecznego. Folia Pomer. Univ. Technol. Stetin., Oeconomica 327(83)2, 288.

Streszczenie. Praktyki studenckie są istotną częścią procesu nauczania, którego zadaniem jest umożliwienie studentom zdobycia kompetencji zawodowych i doświadczenia. Pomimo ściśle określonych efektów uczenia się studenci nie zawsze mogą wykonać wszystkie zadania i zdobyć określone umiejętności. Zakres oczekiwań studentów i różnice, jakie dostrzegają w praktyce, zostały opisane na podstawie przeprowadzonego badania. 